\begin{tabular}{|c|c|}
\hline 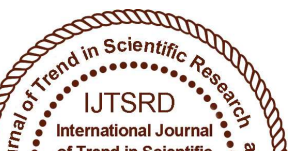 & $\begin{array}{l}\text { International Journal of Trend in Scientific } \\
\text { Research and Development (IJTSRD) }\end{array}$ \\
\hline 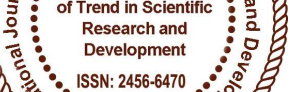 & International Open Access Journal \\
\hline 000 & ISSN No: 2456 - 6470 | www.ijtsrd.com | Volume - 2 | Issue - 3 \\
\hline
\end{tabular}

\title{
Utilization of Waste Polythene as Low Cost and Eco-Friendly Material in PPC Concrete
}

\section{Sudhir Kumar}

Assistant Professor, Department of Civil Engineering, University Institute of Engineering and Technology, Babasaheb Bhimrao Ambedkar University, Lucknow, Uttar Pradesh, India

\author{
Manish Chaudhary \\ Department of Civil Engineering, The Sam \\ Higginbottom University of Agriculture, \\ Technology and Sciences, \\ Allahabad, Uttar Pradesh, India
}

\begin{abstract}
The rapid growth of urbanization and industrialization in the world leads to lot of infrastructure development. And this creates several problems like shortage of construction materials, increased wastes production, etc. From many decades concrete is a versatile material for construction. Concrete is a mixture of cement, coarse aggregate, fine aggregate and water. Now days, construction industries is in need of finding cost-effective and cheap materials for increasing the strength of concrete structures. Hence an attempt has been made in this analysis or investigations to study the impact of addition of domestic waste or very cheap material like polythene waste.
\end{abstract}

In this paper, there is a reuse of waste polythene as partial replacement of coarse aggregate in M25 concrete conforming to IS:10262-2009 guidelines was designed as the referral concrete with the mix proportion of (1:1.54:3) and water-cement ratio(W/C) of 0.45 by weight taking with $0.6 \%$ super plasticizer dose by weight of cement. It is observed that, the compressive strength increases up to the optimum percentage of waste polythene $(0.80 \%$ of weight of cement) and after that it tends to decrease. I also observed that, the flexural strength increases with increase in percentage of waste polythene in concrete. However, the optimum dose of polythene is $0.80 \%$ (by weight of cement).
Keyword: Concrete, plastics, Compressive strength, Flexural Strength

\section{INTRODUTION}

As the world population grows, there is a crisis of construction materials, increased wastes production, etc. One solution to this crisis is recycling wastes into useful products. The wastes plastic in household is large and increases with time. In every country the waste composition is different to each other, since it is affected by many characteristics like socioeconomic characteristics, consumption patterns and waste management programs, but in general the level of plastics in waste composition is too high. The largest component of the plastic waste is polyethylene, followed by polypropylene, polyethylene Terepthalate and polystyrene ${ }^{3}$. The large volume of materials required for construction is potentially a major area for the reuse of waste materials. Recycling in concrete has many advantages since it is widely used and has a long service life, which means that the waste is being removed from the waste stream for a long period. ${ }^{3}$ Because the amount of mineral aggregates required in concrete is too large, the environmental benefits are not only related to the safe disposal of bulk waste, but also to the reduction of environmental impacts arising from the extraction of aggregates.

By using these plastic wastes in concrete will lead to sustain the concrete design and protect the environment. The properties of plastic that make it so 
precious also make its disposal challenging, such as its durability, light weight and low cost. In many cases, plastics are thrown away after one use, especially packaging and sheeting, but they are durable and persist in the environment. Soroushianet al. (1995) stated that polypropylene can be used as synthetic fibers to increase the toughness of concrete. Choi et al. (2005) investigated the effects of waste PET bottles aggregate on the properties of concrete. According to Gupta et al. (2006), the value of segregation index increases with the increase in the amount of marble powder as a replacement of fly ash. Marzouket al. (2007) reported that the plastic bottlesshredded into small (PET) particles may be used successfully as sand-substitution aggregates in cementious concrete composites which appear to offer an attractive low-cost material with consistent properties. Bataynehet al. (2007) found that glass containing concrete composites was the most consistent composite than fiber glass within the selected range of 5 and $20 \%$ aggregate substitutes. Plastic is still a relatively new material, which means the problem of plastic waste has only recently been realized and has knowledge about its environmental persistence (Barnes et al., 2009). Kandasamy et al. (2011), investigated that the compressive strength of concrete Increased in 7 days to an extent of $0.68 \%$; and compressive strength of concrete Increased in 28 days to an extent of $5.12 \%$; at the addition of $0.5 \%$ of polythene (domestic waste polythene bags) fiber to concrete. Murali et al. (2012) observed that concrete blocks incorporated with steel powder increased its compressive strength by $41.25 \%$ and tensile strength by $40.81 \%$. Soft drink bottle caps reinforced blocks exhibited an increase in flexural strength of concrete by $25.88 \%$. Ravikumar et al. (2015)Reported that Concrete produced by replacing natural sand by manufactured sand with addition of $0.5 \%$ of plastic fibres imparts higher compressive, flexural and split tensile strengths due to sharp edges and better interlocking of M-sand particles and good bonding with other materials. The compressive strength of $100 \%$ replaced manufactured sand concrete with $0.5 \%$ of plastic.

\section{MATERIAL AND METHODOLOGY}

1) Cement- In this study, Portland Pozzolana Cement (fly ash based) of (Prism Brand) single batch was used conforming to IS 1489(part I):1991 specification. Properties of PPC are as listed below in table 1.
Table-1, Properties of Portland Pozzolana cement (PPC)

\begin{tabular}{|l|l|}
\hline \multicolumn{1}{|c|}{ Properties } & \multicolumn{1}{|c|}{$\begin{array}{c}\text { Result } \\
\text { value }\end{array}$} \\
\hline Initial setting time & 135 minutes \\
\hline Final setting time & 265 minutes \\
\hline Standard consistency \% & $32 \%$ \\
\hline $\begin{array}{l}\text { Fineness(\% retained on 90 in } \\
\text { sieve) }\end{array}$ & $3.65 \%$ \\
\hline Specific gravity & 2.73 \\
\hline Soundness(Le-chatelier expansion) & $0.65 \mathrm{~mm}$ \\
\hline
\end{tabular}

2) Fine Aggregate-Fine aggregate (FA) used in this investigation was the natural river sand passing completely through $4.75 \mathrm{~mm}$ aperture size sieve and conforming to zone II as per IS:383-1970 specification. Its fineness modulus and specific gravity were 2.75 and 2.34 respectively and bulk density1.694 kg/liter. Particle size distribution as grading curve of the recorded sieve analysis test result for the same is shown in figure 1 with Upper and Lower Permissible limits (UPL and LPL) as per codal recommendation.

3) Coarse Aggregate-Coarse Aggregate are the stone that are retained on $20 \mathrm{~mm}$ and $10 \mathrm{~mm}$ sieve. Coarse aggregate are locally available quarry having two different size, one .A Combined grading of the two individual $20 \mathrm{~mm}$ and $10 \mathrm{~mm}$ Nominal size coarse aggregate $(20 \mathrm{~mm} \mathrm{CA} \mathrm{\&} 10 \mathrm{~mm} \mathrm{CA})$ grading was used with the ratio of these coarse aggregates as 60:40 respectively. Particle size distribution curve of the Achieved Combined coarse aggregate with these two (20 $\mathrm{mm}$ and $10 \mathrm{~mm}$ ) coarse aggregate by the Recorded sieve analysis test result with permissible limits (UPL \& LPL) is shown in figure 2. Properties of the Achieved Combined coarse Aggregate (CCA) of $20 \mathrm{~mm}$ Nominal size are shown in Table 2.

Table-2, Properties of Coarse Aggregate (CA)

\begin{tabular}{|l|l|l|}
\hline \multicolumn{2}{|c|}{ Properties } & \multicolumn{1}{|c|}{$\begin{array}{c}\text { Result } \\
\text { value }\end{array}$} \\
\hline $\begin{array}{l}\text { Fineness } \\
\text { Modulus }\end{array}$ & $\begin{array}{l}10 \mathrm{~mm} \mathrm{Aggregate} \\
(10 \mathrm{~mm} \mathrm{CA})\end{array}$ & 6.425 \\
\cline { 2 - 3 } $\begin{array}{l}20 \mathrm{~mm} \mathrm{Aggregate} \\
(20 \mathrm{~mm} \mathrm{CA})\end{array}$ & 7.421 \\
\cline { 2 - 3 } & $\begin{array}{l}\text { Combined Coarse } \\
\text { Aggregate (CCA) }\end{array}$ & 6.923 \\
\hline Water absorption (\%) & 0.85 \\
\hline Specific gravity & 2.65 \\
\hline
\end{tabular}


4) Waste Polythene: The waste polythene used in this study is shown in fig. 1. It was shredded in very fine random fibre form. The specific gravity for polythene waste is 0.41 and aspect ratio lies between 250 and 500 .

However, similar material properties were reported by Ankit et al.

5) Super Plasticizer- Sulphonated naphthalene formaldehyde (SNF) based Super plasticizer (KEM SUPLAST $101 \mathrm{~S}$ ) of Chembond chemicals was used which conforms to IS:9103-1999 specifications. It was in liquid form compatible with the used Cement, brown in colour having specific gravity 1.2 and It showed good deflocculation and dispersion with cement particles to enhance the workability of concrete mix.

6) Mix Design of the Referral Concrete-M-25 grade of concrete conforming to IS:10262-2009 guidelines was designed as the referral concrete with the mix proportion of (1:1.54:3) and water-cement ratio(W/C) of 0.45 by weight taking with $0.6 \%$ super plasticizer dose by weight of cement.

7) Water -Potable water was used for mixing the concrete mix in entire investigation and for curing the concrete in the determination of the optimal percentage of stone dust as fine aggregate replacement.

\section{EXPERIMENTAL DESIGN}

The cubes were cast in steel moulds of inner dimensions of $150 \times 150 \times 150 \mathrm{~mm}$, all the materials are weighed as per mix proportion of $1: 1.54: 3$ with a $\mathrm{W} / \mathrm{C}$ ratio of 0.45 which correspond to M25 grade of concrete. Cement is replaced by waste polythene. Each mix comprises of various percentages of cement replacement material in increasing order i.e. $0.20 \%$, $0.40 \%, 0.60 \%, 0.80 \%$ and $1.00 \%$, respectively in replacement. The specimens were cured for a period of 7, 28 and 56 days.

\section{RESULT AND DISCUSSION}

A. Compressive Strength of waste polythene concrete: - The compressive strength of concrete made using polythene waste after 7, 28 and 56 days are given in table 3. It is observed that the compressive strength at 28 days was not meeting the target mean strength of M-25 grade concrete. This may be due to the use of super plasticizer which to some extent acts as retarder. However, the strength at 56 days is satisfactory. The results of compressive strength test are shown graphically in figure-1 for visual observation. It is observed that, the compressive strength increases up to the optimum percentage of waste polythene $(0.80 \%$ of weight of cement) and after that it tends to decrease. However, the strength of $1 \%$ waste polythene concrete is also more than that of referral concrete.

Table - (3) Average compressive strength of plastic waste concrete $(\mathrm{W} / \mathrm{C}=\mathbf{0 . 4 5})$

\begin{tabular}{|c|c|c|c|c|c|}
\hline \multirow[t]{2}{*}{$\begin{array}{l}\text { S. } \\
\text { No. }\end{array}$} & \multirow{2}{*}{$\begin{array}{l}\text { Cube } \\
\text { Design- } \\
\text { ation }\end{array}$} & \multirow{2}{*}{$\begin{array}{l}\text { Polythene } \\
\text { waste } \\
\text { replacement } \\
\text { level }(\%)\end{array}$} & \multicolumn{3}{|c|}{$\begin{array}{c}\text { Compressive } \\
\text { strength }\left(\mathbf{N} / \mathbf{m m}^{2}\right)\end{array}$} \\
\hline & & & $\begin{array}{c}7 \\
\text { Days }\end{array}$ & $\begin{array}{c}28 \\
\text { Days }\end{array}$ & $\begin{array}{c}56 \\
\text { Days }\end{array}$ \\
\hline 1 & B1 & 0 & 24.35 & 31.70 & 35.64 \\
\hline 2 & B2 & 0.20 & 23.88 & 33.48 & 36.86 \\
\hline 3 & B3 & 0.40 & 24.65 & 32.86 & 36.65 \\
\hline 4 & B4 & 0.60 & 24.98 & 34.18 & 37.64 \\
\hline 5 & B5 12 & 0.80 & 25.15 & 34.54 & 38.12 \\
\hline $6 \mathrm{C}$ & B6 & 1.00 & 24.36 & 32.12 & 38.45 \\
\hline
\end{tabular}

\section{Compressive strength of waste polythene concrete}

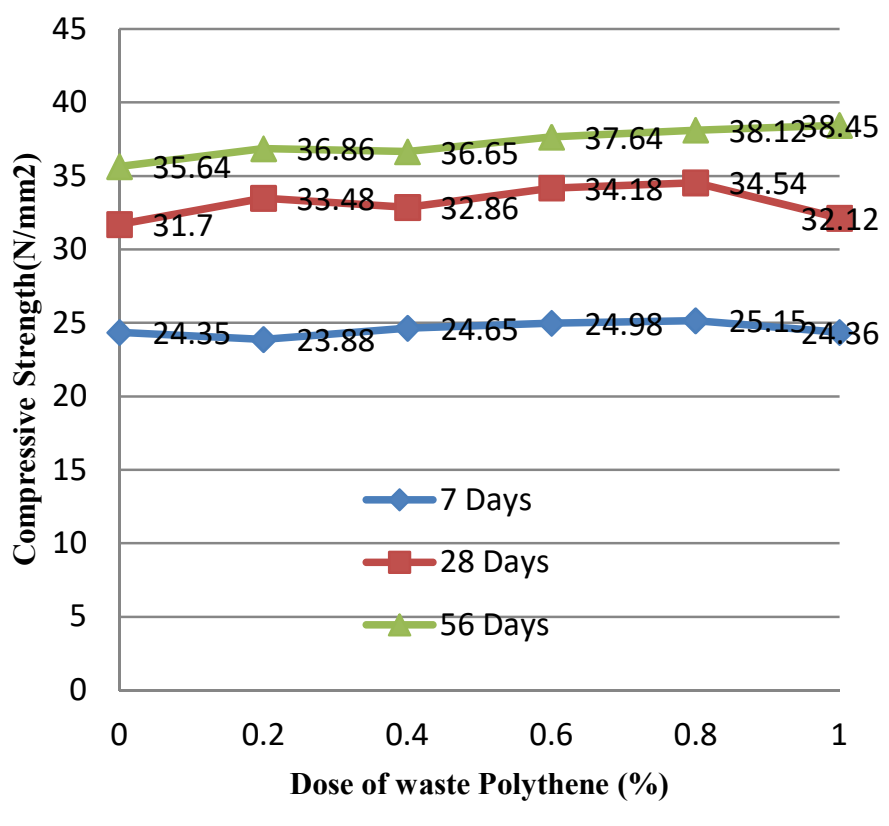

Figure-1, Variation of compressive strength with replacement level (\%) of cement 
International Journal of Trend in Scientific Research and Development (IJTSRD) ISSN: 2456-6470

B. Split tensile strength of waste polythene concrete: The split tensile strength of concrete mixes by partial replacement of cement by waste polythene fiber was cast cylinder and tested at 7, 14 and 28 days.. The experimental set up for determination of split tensile strength is shown in table-4. These results are shown graphically also in figure-2, for visual observation. It is observed that, the split tensile strength increases with increase in percentage of waste polythene in concrete. However, the optimum dose of polythene is $0.80 \%$ (by weight of cement).

\section{Table - (4) Split tensile strength of concrete} $(\mathbf{w} / \mathrm{c}=\mathbf{0 . 4 5})$

\begin{tabular}{|c|c|c|c|c|c|}
\hline \multirow[t]{2}{*}{$\begin{array}{l}\text { S. } \\
\text { No. }\end{array}$} & \multirow[t]{2}{*}{$\begin{array}{l}\text { Cube } \\
\text { Design- } \\
\text { ation }\end{array}$} & \multirow{2}{*}{$\begin{array}{l}\text { Polythene } \\
\text { waste } \\
\text { replacement } \\
\text { level (\%) }\end{array}$} & \multicolumn{3}{|c|}{$\begin{array}{c}\text { Split tensile } \\
\text { strength of } \\
\text { concrete }\left(\mathrm{N} / \mathrm{mm}^{2}\right)\end{array}$} \\
\hline & & & $\begin{array}{c}7 \\
\text { Days }\end{array}$ & $\begin{array}{c}28 \\
\text { Days }\end{array}$ & $\begin{array}{c}56 \\
\text { Days }\end{array}$ \\
\hline 1 & $\mathrm{C} 1$ & 0 & 3.12 & 4.15 & 4.65 \\
\hline 2 & $\mathrm{C} 2$ & 0.20 & 3.42 & 4.28 & 4.70 \\
\hline 3 & C3 & 0.40 & 3.53 & 4.64 & 5.82 \\
\hline 4 & C4 & $0.60=$ & 3.62 & 5.16 & 5.60 \\
\hline 5 & C5 & $0.80 \bigcirc$ & 3.75 & 5.78 & 6.12 \\
\hline 6 & C6 & 1.00 & 3.25 & 4.35 & $\begin{array}{l}5.72 \\
\mathrm{~V} / \mathrm{e}\end{array}$ \\
\hline
\end{tabular}

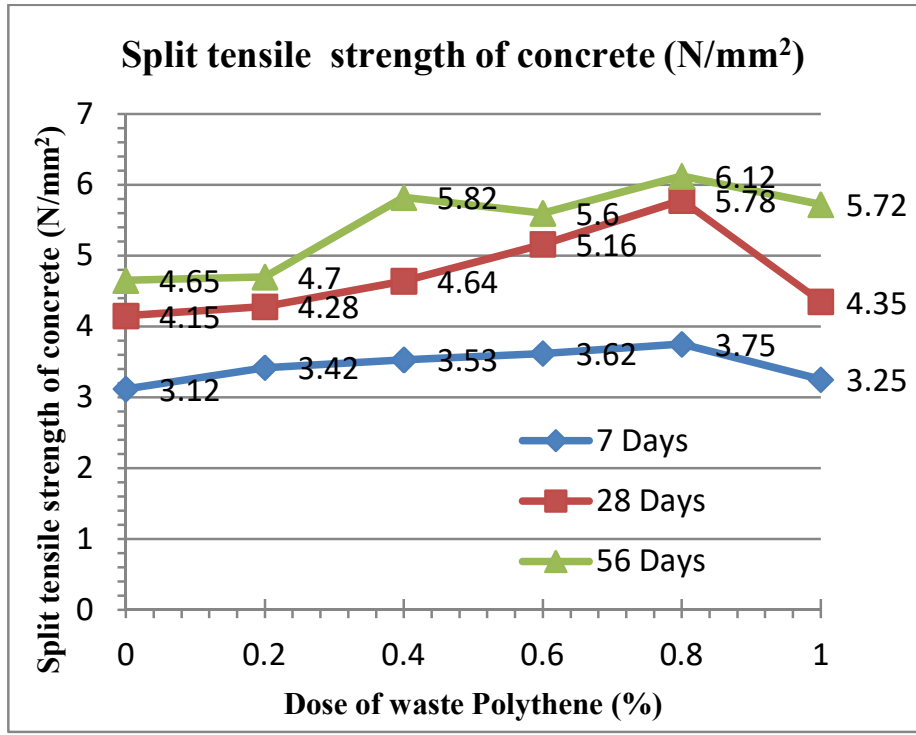

Figure-2, Variation of Split tensile strength of concrete with replacement level (\%) of cement

\section{Conclusion:}

On the bases of experimental investigation the following conclusions are presented.
Waste polythene is to be used as cement replacement of Portland Pozzolana cement (PPC) in concrete as partially.

While using waste polythene as partial replacement of Portland Pozzolana Cement (PPC) in concrete increased the workability with increased in replacement level.

Compressive strength of concrete made using waste polythene used as partial replacement of cement. The optimum replacement level of waste polythene in cement is $0.80 \%$.

$>$ Split tensile strength of concrete made using waste polythene as partial replacement of cement.

Use of waste polythene powder as cement in concrete is beneficial in different manners such as environmental aspects and strength criteria also.

\section{References:}

1) V. Kasselouri - Rigopoulou, S. Gavela, S. Kolias "Use Of Polymeric Wastes in The Concrete Production" Polymers in concrete: a vision for the 21st century, Cement \& Concrete Composites 21: (1999) 449-452.

2) NitishPuri, Brijesh Kumar, HimanshuTyagi," Utilization of Recycled Wastes as Ingredients in Concrete Mix," International Journal of Innovative Technology and Exploring Engineering (IJITEE) ISSN: 2278 3075, Volume 2, Issue -2, January 2013.

3) R. Anuradha et al, Utilisation of Waste Plastics as a Replacement of Coarse Aggregate in Paver Blocks. International Journal of ChemTech Research CODEN (USA): IJCRGG, ISSN: 09744290, ISSN(Online):2455-9555 Vol.10 No.8, pp 211-218, 2017.

4) Manish Chaudhary et al, Effect of Waste Low Density Polyethylene on Mechanical Properties of Concrete. Journal of Academia and Industrial Research (JAIR) Volume 3, Issue 3 August 2014 123CYouth Education and Research Trust (YERT) jairjp.com, ISSN: 2278-52132014.

5) IS 1489:1991. Portland-Pozzolana CementSpecification-Part 1: Fly Ash Based, Bureau of Indian standard institution, New Delhi.

6) IS: 10262:1982. Recommended guidelines for concrete mix design, Bureau of Indian standards, New Delhi. 
7) IS: 2386-1963. Indian standards code of practice for methods of test for Aggregate for concrete, Bureau of Indian standard Institution, New Delhi.

8) IS: 383-1970. Specification for coarse and fine aggregates from natural sources for concrete" (Second revision)

9) IS: 456-2000. Specifications for plain and reinforced concrete.

10) IS: 516-1959. Method of test for strength of concrete Bureau of Indian standards. New Delhi, India.

11) K. Soman, DivyaSasi, and K.A Abubaker, "Strength properties of concrete with partial replacement of sand by bottom ash," International Journal of Innovative Research in Advanced Engineering (IJIRAE), ISSN:2349-2163, Volume 1 Issue 7 (August 2014).

12) R. Kandasamy and R. Murugesan (2011) "FIBRE REINFORCED CONCRETE USING DOMESTIC WASTE PLASTICS AS FIBRES", ARPN Journal of Engineering and Applied Sciences, VOL. 6, NO. 3, MARCH 2011 ISSN 1819-6608.

13) G.Murali, C.M.Vivek Vardhan, R.Prabu, Z.Mohammed Sadaquath Ali Khan, T.Aarif Mohamed And T.Suresh,(2012), "Experimental investigation on fibre reinforced concrete using waste materials" International Journal Of Engineering Research And Applications (ijera) issn: 2248-9622 www.ijera.com vol. 2, issue 2,mar-apr 2012, pp.278-283.

14) Ravikumar G and Manjunath / M (2015) "Investigation on Waste Plastic Fibre Reinforced Concrete Using Manufactured Sand as Fine Aggregate", International Research Journal of Engineering and Technology (IRJET) 6 Volume: 02 Issue: 04 July-2015 www.irjet.net p-ISSN: 2395-0072 e-ISSN: 2395 -005. 